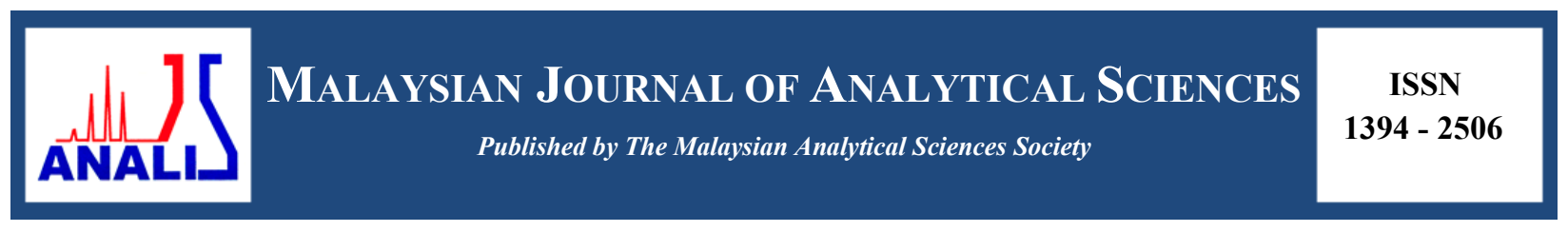

\title{
CHEMICAL CHARACTERIZATION OF Berberis vulgaris L. var. asperma EDIBLE BERRIES
}

\author{
(Pencirian Kimia Buah Beri Boleh di Makan Berberis vulgaris L. var. asperma)
}

\author{
Maria Carmen S. Tan ${ }^{1}$, Irving D. Chiong ${ }^{1}$, Mary Stephanie S. Carranza ${ }^{1}$, Regina M. Salmasan ${ }^{1}$, Glenn G. Oyong ${ }^{2}$ \\ ${ }^{1}$ Chemistry Department \\ ${ }^{2}$ Molecular Science Unit Laboratory, Center for Natural Science and Environmental Research \\ De La Salle University, 2401 Taft Avenue, Manila 1004, Philippines \\ *Corresponding author: maria.carmen.tan@dlsu.edu.ph
}

Received: 11 January 2018; Accepted: 4 June 2018

\begin{abstract}
Berberis vulgaris L. var. asperma edible fruits have been found to have activity against several microbes and to be cytotoxic in certain immortalized cancer cell lines. In this study, the berries were analyzed to find the possible metabolites that could be the curative agents. Evaluations using an LC-UV/MS technique established the presence of chlorogenic acid, rutin, and berberine in ethanolic extracts of $B$. vulgaris berries. The ethanolic sample was found to have $47.1 \mathrm{mg} / \mathrm{kg}$ of 3-(3,4-dihydroxycinnamoyl) quinic acid, $0.02 \mathrm{mg} / \mathrm{kg}$ of rutin and $0.36 \mathrm{mg} / \mathrm{kg}$ of berberine. The free radical scavenging activity of the mixture of polyphenolics exhibited an $\mathrm{IC}_{50}$ at $34.48 \mu \mathrm{g} / \mathrm{mL}$. An assessment of zinc and iron concentration using atomic absorbance spectrophotometry (AAS) was determined to be 45.3 and $198.1 \mathrm{mg} / \mathrm{kg}$, respectively. The investigation of the volatile constituents through solid phase microextraction (SPME) and by dichloromethane extraction was explored using a gas chromatograph equipped with a mass spectrometer (GC-EI-MS). SPME analyses showed the presence of palmitic acid (C16:0), vaccenic acid (C18:1 $\Delta 11$ trans) and stearic acid (C18:0). Three saturated fatty acids, SFAs (C14:0, C16:0, and C18:0), two methyl esters of the SFAs (C14:0 and C16:0), and one polyunsaturated fatty acid, PUFA (C18:2 $\Delta$ 9,12 cis) were detected in the dichloromethane extracts of the berries.
\end{abstract}

Keywords: atomic absorption spectroscopy, Berberis vulgaris, mass spectrometry

\section{Abstrak}

Buah yang boleh dimakan Berberis vulgaris L. var. asperma telah diketahui mempunyai aktiviti melawan beberapa jenis mikrob and menjadi sitotoksik di dalam sesetengah titisan sel kekal. Dalam kajian ini, buah beri dianalisis untuk mencari kebarangkalian metabolit yang boleh digunakan sebagai agen penawar. Penilaian menggunakan teknik LC-UV/MS dibangunkan untuk mengesan kehadiran asid klorogenik, rutin dan berberin di dalam ekstrak beri B.vulgaris. Sampel etanolik ditemui mengandungi $47.1 \mathrm{mg} / \mathrm{kg} 3-(3,4$ - dihidroksisinamoil) asid quinik, $0.02 \mathrm{mg} / \mathrm{kg}$ rutin dan $0.36 \mathrm{mg} / \mathrm{kg}$ berberin. Pemerangkapan aktiviti radikal bebas bagi campuran polifenolik wujud pada $\mathrm{IC}_{50} 34.48 \mu \mathrm{g} / \mathrm{mL}$. Penilaian kepekatan zink dan besi menggunakan spektrofotometri serapan atom (AAS) telah ditentukan dengan masing-masing ialah 45.3 dan $198.1 \mathrm{mg} / \mathrm{kg}$. Penyiasatan terhadap jujukan sebatian merupa dilakukan menggunakan pengekstrakan mikro fasa pepejal (SPME) dan pengekstrakan diklorometana sebelum di analisis menggunakan kromatograf gas dilengkapi spektrometer jisim (GC-EI-MS). Analisis SPME menunjukkan kehadiran asid palmitik (C16:0), asid vasenik (C18:1 $\Delta 11$ trans) dan asid stearik (C18:0). Tiga asid lemak tepu, SFAs (C14:0, C16:0, dan C18:0), dua metal ester SFAs (C14:0 and C16:0), and satu asid lemak politaktepu, PUFA (C18:2 $\Delta$ 9,12 cis) telah dikesan di dalam ekstrak diklorometana buah beri.

Kata kunci: spektroskopi serapan atom, Berberis vulgaris, spektrometri jisim 


\section{Introduction}

Berberis vulgaris is a member of the Barberdaceae family and a common garden bush found in Europe and the British Isles. Barberry, as it is commonly known, has been used by herbalists since ancient times with its usage dating back to the Egyptians. Alkaloids and flavonoids have been reported in the root, stem, leaves and fruit of this bush. These two compound classes have been found to exhibit anti-diarrheal, anti-microbial, anti-inflammatory, anti-allergic, and anti-cancer effects. The edible fruit of B. vulgaris has been used in Asia and Europe especially in Iran as traditional medicine for various diseases which include malaria, dysentery and gall stones. Its antihistaminic and anticholinergic activity was found in the aqueous extracts of barberry on isolated guinea pig ileum [1]. Antioxidant activities of ethanolic extracts of roots, twigs, and leaves of the barberry plant were correlated with phenols and flavonols present in the plant tissue [2]. The fruit has been linked to diseases of the kidneys, urinary or gastrointestinal tract, liver, bronchial, and as a stimulant for the circulatory system [3].

In this work, ethanolic extracts of the barberry fruit were analyzed using a radical scavenging assay, highperformance liquid chromatography (HPLC), liquid chromatography-mass spectrometry (LC-ESI-MS), gas chromatography-mass spectrometry (GC-EI-MS), solid-phase microextraction (SPME) and dichloromethane extracts, and atomic absorption spectrometry (AAS). To the best of our knowledge, this is the first reported study using this methodology of chemical analyses on the extracts of B. vulgaris berries.

\section{Materials and Methods}

Fresh samples of B. vulgaris fruits were harvested from Mashhad, Khorasan Province, Iran and identified at the Mashhad Medical University of Sciences, Iran. The berries were lyophilized and extracted with ethanol for 10 hours, filtered ( $22 \mu \mathrm{m}$ pore size $)$, and concentrated in vacuo. The residue was reconstituted with ethanol $(60 \mu \mathrm{g} / \mu \mathrm{L})$ and was passed through a $0.45 \mu \mathrm{m}$ cellulose acetate membrane before further analysis.

\section{Free radical scavenging assay}

The radical scavenging activity of $B$. vulgaris ethanolic fruit extracts was measured by 2,2-Diphenyl-1picrylhydrazyl or DPPH (Sigma-Aldrich, Singapore) utilizing a modified version of the method by Sikder et al. [4]. An amount $10 \mathrm{~mL}$ of $60 \mathrm{mM}$ of DPPH was added to each trial where the extracts were varied from $5 \mu \mathrm{L}$ to $125 \mu \mathrm{L}$. The resulting reaction mixtures of 30.00 to $740.74 \mu \mathrm{L} / \mathrm{mL}$ were incubated at ambient temperatures in the dark for 30 minutes. A control sample which contained only DPPH solution and no fruit extract was also made. After incubation, changes in absorbance at $517 \mathrm{~nm}$ were analyzed using a Hitachi 2900 double beam UV-Visible spectrophotometer. Nonlinear regression and statistical analyses were done using GraphPad Prism 7.01 (GraphPad Software, Inc.) to extrapolate the half maximal inhibitory concentration, $\mathrm{IC}_{50}(50 \%$ reduction of absorbance as compared to the control).

\section{RP-HPLC analyses}

Fruit extracts $(20 \mu \mathrm{L})$ were analyzed using an Agilent Technologies 1200 Series quaternary pump system with a variable wavelength detector and a $20-\mu \mathrm{L}$ sample injector. Analytes were separated on a $250 \mathrm{~mm} \times 4 \mathrm{~mm}, 5-\mu \mathrm{m}$ particle RESTEK Pinnacle II ODS column (Supelco). Resolved compound peaks were identified by direct comparison of their retention times with reference standards. The columns were maintained at room temperature.

Optimization was conducted using a method developed by Hasler et al. [5] and Olszewska [6]. Solvent system consisted of $5 \%$ formic acid in distilled water $\left(\mathrm{FA} / \mathrm{H}_{2} \mathrm{O}\right)$ and acetonitrile $(\mathrm{ACN})$ with a gradient of: $0-2$ minutes at 95\% $\left(\mathrm{FA} / \mathrm{H}_{2} \mathrm{O}\right)$ and $5 \% \mathrm{ACN} ; 5-7$ minutes at 90\% $\left(\mathrm{FA} / \mathrm{H}_{2} \mathrm{O}\right)$ and $10 \% \mathrm{ACN} ; 7-10$ minutes at $90-85 \%\left(\mathrm{FA} / \mathrm{H}_{2} \mathrm{O}\right)$ and $10-15 \% \mathrm{ACN} ; 10-13$ minutes at $85-80 \%\left(\mathrm{FA} / \mathrm{H}_{2} \mathrm{O}\right)$ and $15-20 \% \mathrm{ACN} ; 13-23$ minutes $80 \%\left(\mathrm{FA} / \mathrm{H}_{2} \mathrm{O}\right)$ and $20 \%$ $\mathrm{ACN} ; 23-25$ minutes at $80-70 \%\left(\mathrm{FA} / \mathrm{H}_{2} \mathrm{O}\right)$ and $20-30 \% \mathrm{ACN} ; 25-28$ minutes at $70 \%\left(\mathrm{FA} / \mathrm{H}_{2} \mathrm{O}\right)$ and $30 \% \mathrm{ACN} ; 30-$ 32 minutes at 50\% $\left(\mathrm{FA} / \mathrm{H}_{2} \mathrm{O}\right)$ and $50 \% \mathrm{ACN}$; 32-45 minutes at 50-95\% $\left(\mathrm{FA} / \mathrm{H}_{2} \mathrm{O}\right)$ and $50-5 \%$ ACN. Flow rate was $1.00 \mathrm{~mL} / \mathrm{min}$, while the UV detector was set at $350 \mathrm{~nm}$ for all the trials. Standard stock solutions initially from 500 ppm of berberine (Sigma-Aldrich, Singapore), rutin (Sigma-Aldrich, Singapore), and chlorogenic acid (SigmaAldrich, Singapore) were freshly prepared in methanol and the goodness of fit generated from the absorbance per concentration on scatter charts confirmed whether the linear regression analysis $\left(\mathrm{R}^{2}>0.97\right)$ and external calibration were acceptable. 


\section{LC-ESI-MS analyses}

Fruit extracts were analyzed using LC-MS system equipped with DIONEX Ultimate 3000 HPLC \& Bruker micrOTOF-Q II MS with a $\mathrm{C}_{18}$ column $(3 \mathrm{~mm}, 120 \AA$, 2.1 x $150 \mathrm{~mm}$ ). Electrospray ionization positive mode was used and acquisition was at $50 \mathrm{~m} / \mathrm{z}$ to $3000 \mathrm{~m} / \mathrm{z}$. The solvent gradient for RP-HPLC was used, with the last segment of the gradient extended for five minutes to account for the internal calibration (sodium formate) that was run simultaneously with the trials. Other parameters were as follows: capillary at $4500 \mathrm{~V}$, end plate offset at $-500 \mathrm{~V}$, collision cell RF 500.0 VPP, nebulizer at 2.0 bar, dry heater at $180^{\circ} \mathrm{C}$, dry gas at $8.0 \mathrm{~L} / \mathrm{min}$. Mass spectra were calibrated internally during the trials and the background subtracted during data analysis.

\section{SPME-GC-EI-MS analyses}

Approximately 7 grams of lyophilized fruit extracts were placed in an Erlenmeyer flask covered with a septum. Samples for GC-MS analysis was collected using a polydimethylsiloxane (PDMS) fiber while heating the set-up at $40{ }^{\circ} \mathrm{C}$ for 30 minutes. The fiber was desorbed and analyzed manually in a Perkin-Elmer Clarus 500 gas chromatograph - mass spectrometer. Sampling rate was 1.56250 points/second. Temperature was set at $40{ }^{\circ} \mathrm{C}$ for 5 minutes then increased by $4{ }^{\circ} \mathrm{C}$ until it reached $230{ }^{\circ} \mathrm{C}$ where it was held for 5 minutes. Flow rate of the carrier gas was set at $2.0 \mathrm{~mL} / \mathrm{min}$ while ionization was carried out using $70 \mathrm{eV}(\mathrm{EI})$, and the masses were scanned from $50 \mathrm{~m} / \mathrm{z}$ to $500 \mathrm{~m} / \mathrm{z}$.

\section{GC-EI-MS analyses of DCM extracts}

The freeze-dried B. vulgaris berries $(9.37 \mathrm{~g})$ were ground in an osterizer, soaked in $\mathrm{CH}_{2} \mathrm{Cl}_{2}(\mathrm{DCM})$ for one day, filtered, and concentrated over nitrogen gas to achieve the resultant crude residue $(5.25 \mathrm{~g})$ which was then redissolved in $1 \mathrm{~mL}$ of DCM. An Agilent GC MS 7890B, equipped with a HP-5ms (5\% phenyl methylsiloxane) Ultra Inert column ( $30 \mathrm{~m} \times 250 \mathrm{~mm} \times 0.25 \mathrm{~mm})$ with ultra-pure helium gas as the mobile phase, was used for the analysis of volatile constituents. The flow rate of helium gas was at $1 \mathrm{~mL} / \mathrm{min}$, pressure maintained at 8.2 psi, with an average velocity of $36.62 \mathrm{~cm} / \mathrm{sec}$ and holdup time of 1.37 minutes. The split inlet, at 20:1 ratio, was held at $250{ }^{\circ} \mathrm{C}$, at $8.2 \mathrm{psi}$, total flow of $24 \mathrm{~mL} / \mathrm{min}$, with a septum purge flow rate of $3 \mathrm{~mL} / \mathrm{min}$. The temperature for the injector was held at $250{ }^{\circ} \mathrm{C}$ and optimization of the temperature program was started at $50{ }^{\circ} \mathrm{C}$ with a programmed linear ramp of $5{ }^{\circ} \mathrm{C} / \mathrm{min}$ until $220^{\circ} \mathrm{C}$.

Compound identification was done using the NIST library 2.0 and peak areas were processed from the resultant total ion chromatograms. The resultant data was confirmed by the comparison of the compounds according to their elution order with their relative retention indices on a non-polar stationary phase. The retention indices were computed for all of the volatile constituents utilizing a homologous series of n-alkanes.

\section{AAS analysis}

Approximately $1 \mathrm{~g}$ of lyophilized fruit extract was pulverized and heated in a furnace at $200{ }^{\circ} \mathrm{C}$ to $250{ }^{\circ} \mathrm{C}$ for 30 minutes. Then, the sample was reduced to ashes by heating at $450{ }^{\circ} \mathrm{C}$ for 4 hours. After this, $2 \mathrm{~mL}$ of $5 \mathrm{M} \mathrm{HNO}_{3}$ was added and the resulting mixture was evaporated to dryness in a sand bath. The sample was further dried at $400{ }^{\circ} \mathrm{C}$ for 15 minutes, then the ashes were dissolved in $5 \mathrm{~mL}$ of $20 \% \mathrm{HCl}$ followed by dilution to $25 \mathrm{~mL}$. The zinc and iron content of the sample were analyzed using a Shimadzu AA-6300 atomic absorption spectrophotometer.

\section{Free radical scavenging activity}

\section{Results and Discussion}

Through curve fitting or nonlinear regression of the data points of the varying volumes of barberry extract, the $\mathrm{IC}_{50}$ was found to be $34.48 \mu \mathrm{g} / \mathrm{mL}$. The reaction mixture with $149.63 \mathrm{ppm}$ of barberry extract caused the maximum decrease in absorbance and additional increments of the ethanolic extracts did not exhibit any significant variance $(\mathrm{p}>0.05)$ at $95 \% \mathrm{CI}$ of discrepancy. The extent of decrease in absorbance from the control correlates with the free radical scavenging potential of the antioxidant present in the plant extract [7].

\section{Identification of alkaloids and flavonoids}

Mass spectral analysis of $B$. vulgaris ethanolic fruit extracts resulted in the identification of three compounds (Figure 1). At a retention time of 9.9-10.2 minutes and a molecular weight of $355.1 \mathrm{~m} / \mathrm{z}$, the chemical formula $\mathrm{C}_{16} \mathrm{H}_{19} \mathrm{O}_{9}$ with $-0.1 \mathrm{err}[\mathrm{mDa}],-0.2 \mathrm{err}[\mathrm{ppm}]$, and $2.9 \mathrm{mSigma}$ correlated with $[\mathrm{M}]^{+1}$ of chlorogenic acid or 
3-(3,4- dihydroxycinnamoyl) quinic acid. Rutin, $[\mathrm{M}+\mathrm{H}]^{+1}$, was found at a retention time of $14.2-14.9$ minutes at $611.2 \mathrm{~m} / \mathrm{z}$, with the chemical formula $\mathrm{C}_{27} \mathrm{H}_{31} \mathrm{O}_{16}$ and $1.4 \mathrm{err}[\mathrm{mDa}], 2.2 \mathrm{err}[\mathrm{ppm}]$ and mSigma 4.5. The $[\mathrm{M}+\mathrm{H}]^{+1}$ of berberine, $\mathrm{C}_{20} \mathrm{H}_{18} \mathrm{NO}_{4}$, was found at 17.6 - 17.8 minutes.

\section{Quantitative analysis of chlorogenic acid, berberine and rutin}

From the chromatograms of the ethanolic extract and comparison of the retention times, it was found that chlorogenic acid (polyphenol), rutin (flavonoid) and berberine (alkaloid) were present. Analysis using chlorogenic acid, rutin, and berberine standards gave average retention times of 10.39, 18.58, and 33.81 minutes, respectively. The barberry extracts were found to contain $47.1 \mathrm{mg} / \mathrm{kg}$ of chlorogenic acid, $0.02 \mathrm{mg} / \mathrm{kg}$ of rutin and $0.36 \mathrm{mg} / \mathrm{kg}$ of berberine.

Chlorogenic acid has been found to be an activator of the Nrf2/antioxidant-response element pathway, which was initiated during oxidative stress [8]. The extensive range of therapeutic effects, such as antimutagenic, antiviral [9], anticarcinogenic [7], and free radical scavenging activity [10] has led many researchers to believe that this compound can have potential pharmaceutical applications. Rutin (vitamin P or rutoside) is considered a high value nutraceutical whose pharmacological action has been reported to benefit the central nervous system through its neuroprotective effect on brain ischemia by the upregulation of 'endogenous antioxidant defense enzymes' [11]. A significant attenuation in HL-60 cells in a murine model using a dose of $120 \mathrm{mg} / \mathrm{kg}$ of rutin displayed a high antileukemia capacity [12]. Berberine was found to inhibit gram-positive bacteria such as Staphylococcus aureus (X) with a MIC value of $250 \mathrm{mg} / \mathrm{L}$ [13]. Inhibition of mutant keratinocytes by berberine at $\mathrm{IC}_{50}=30 \mu \mathrm{mol} / \mathrm{L}$ [14] and in HeLa cells at 100 and $150 \mathrm{mg} / \mathrm{L} \mathrm{[15]} \mathrm{were} \mathrm{observed.}$
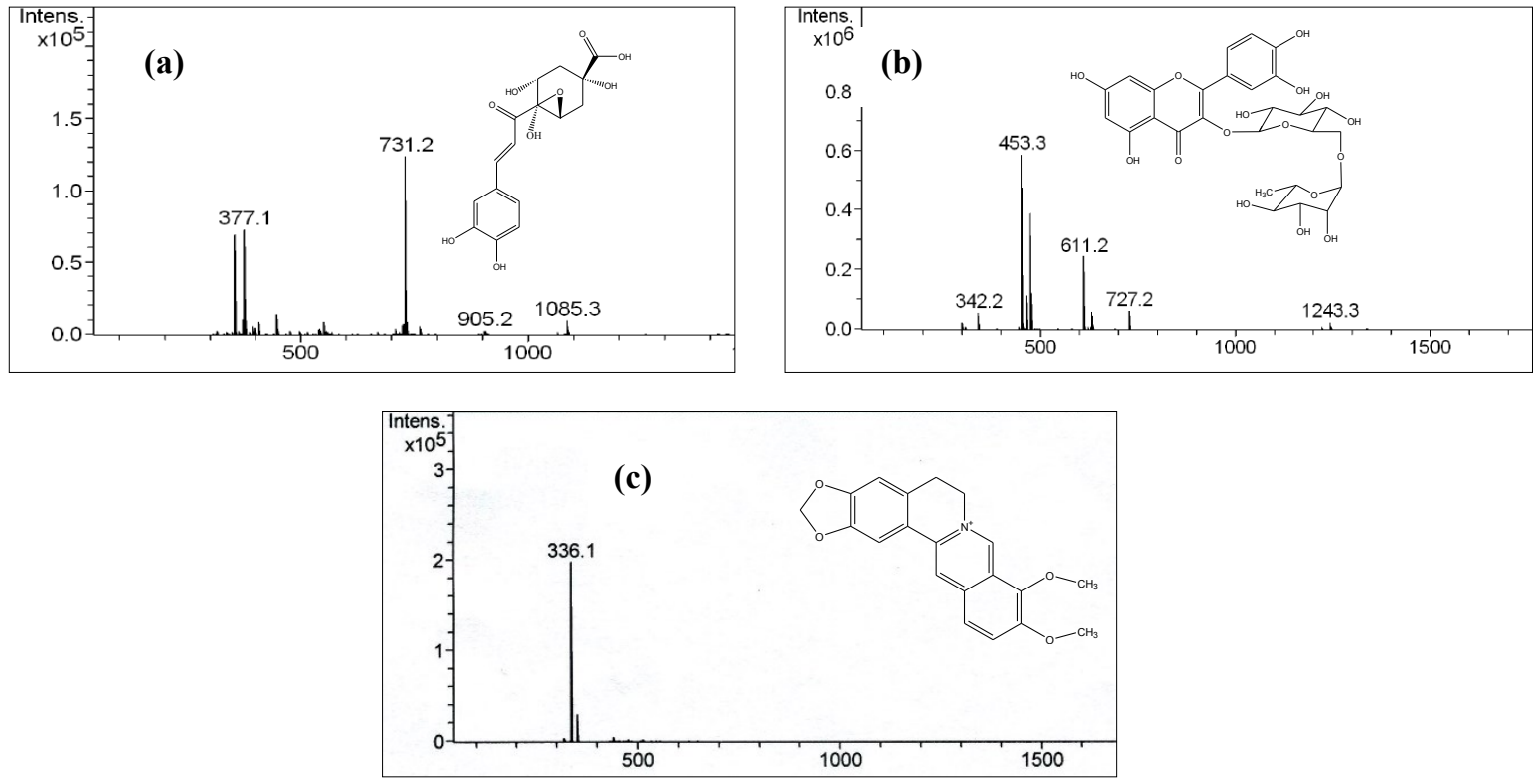

Figure 1. Mass spectra and structures of compounds (a) 1, (b) 2, and (c) 3 found in the LC-ESI-MS analyses

\section{Concentration of zinc and iron}

The barberry samples contained 45.3 and $198.1 \mathrm{mg} / \mathrm{kg}$ of zinc and iron respectively. Streptococcus pyogenes, Staphylococcus aureus and Pseudomonas aeruginosa were found to have physical damage on the bacterial cell membranes due the adhesion of zinc oxide rod structures on the sheaths [16]. Inorganic metal oxides such as iron(II) oxide can also act as operative antiseptics, owing to their innocuous profile, chemical stability and bioactivity against certain microbes. Composite nanoparticle structures oxides of $\mathrm{Zn} / \mathrm{Fe}$ exhibited significant bacteriostatic activity on Staphylococcus aureus and minimally against Escherichia coli [17]. 


\section{SPME-GC-EI-MS Analysis}

Palmitic acid $\left(256.0128 \mathrm{~m} / \mathrm{z},[\mathrm{M}]^{+}\right)$at 45.10 minutes was observed and the spectra showed the fragment $\left[\left(\mathrm{CH}_{2}\right)_{2} \mathrm{CO}_{2} \mathrm{H}\right]^{+}$with $\mathrm{m} / \mathrm{z}=72.9138$. Fragments at 59.9186, 128.9987, 157.0768, 213.0133, and $227.0895 \mathrm{~m} / \mathrm{z}$ also exhibited ions with the formula $\left[\left(\mathrm{CH}_{2}\right) \mathrm{nCO}_{2} \mathrm{H}\right]^{+}$. Vaccenic acid was the most probable compound at 50.29 minutes which manifested a molecular ion peak at $282.1020 \mathrm{~m} / \mathrm{z}$ and a base peak at $54.930 \mathrm{~m} / \mathrm{z}$ which is presumed to be $\left[\mathrm{C}_{4} \mathrm{H}_{7}\right]^{+}$. The peak at 50.77 minutes gave a fragmentation pattern attributed to stearic acid $284.1314 \mathrm{~m} / \mathrm{z}[\mathrm{M}]^{+}$; the base peak was also at $72.9138 \mathrm{~m} / \mathrm{z}$ and exhibited a similar fragmentation pattern to that of palmitic acid. Olefinic fragments at approximately m/z: 69, 83, and 97 were also found in the three mass spectra (Figure 2).
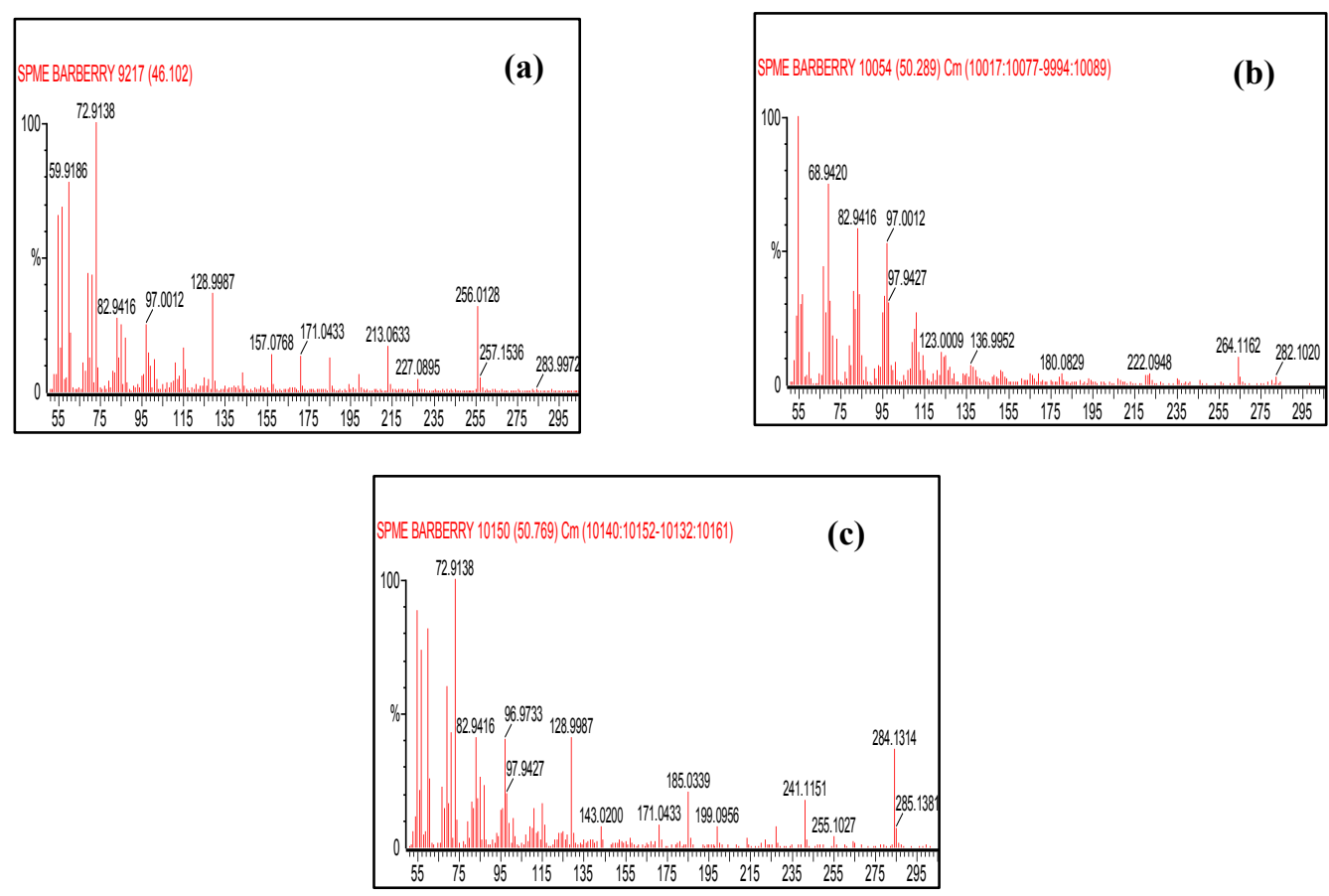

Figure 2. Mass spectra of (a) palmitic acid, (b) vaccenic acid, (c) stearic acid in the SPME-GC-EI-MS analyses

\section{GC-EI-MS analyses of DCM extracts}

GC-MS analyses of the dichloromethane extracts of B. vulgaris edible berries led to the identification of six constituents. The identified components of the low boiling point compounds of the crude extract were substantiated by retention index (RI) and structural class through the NIST library. The results are listed in Table 1 according to their elution order on a HP-5MS column. The sample consisted primarily of three SFAs (C14:0, C16:0, and C18:0), two methyl esters of the SFAs of C14:0 and C16:0, and one PUFA (C18:2 $\Delta$ 9,12 cis).

Antimicrobial function in human milk, skin and mucosal membranes have been linked to the presence of fatty acid in these food products which may have the capacity to be useful as microbicides against human pathogens that occur on the skin and mucosa $[18,19,20]$. Various concentrations of saturated fatty acids (SFAs) capric acid (C10:0), lauric acid (C12:0), myristic acid (C14:0), palmitoleic acid (C16:1), monocaprin (C10:0) monolaurin (C12:0) and monopalmitolein (C16:0) caused significant reduction in $H$. pylori cells [21]. The natural trans-fat vaccenic acid is the natural precursor of the polyunsaturated fatty acid (PUFAs) linoleic acid (C18:2 $\Delta 9,12$ cis) and has been reported to have hypo-triglyceridemic action in JCR:LA-cp rats [22] and have anti-proliferative effects on the immortalized cell line MCF-7 (breast adenocarcinoma) by inhibiting the expression of Bcl-2 and procaspase-9 [23]. 
Tan et al: CHEMICAL CHARACTERIZATION OF Berberis vulgaris L. var. asperma EDIBLE BERRIES

Table 1. The volatile constituents of the B. vulgaris DCM extracts

\begin{tabular}{lcccl}
\hline $\begin{array}{l}\text { Peak } \\
\text { Number }\end{array}$ & $\begin{array}{c}\text { RT } \\
\text { (minutes) }\end{array}$ & Compound $^{\mathbf{b}}$ & RI $^{\mathbf{a}}$ & Functionality \\
\hline 1 & 14.75 & tetradecanoic acid & 1766 & saturated fatty acid \\
2 & 17.55 & hexadecanoic acid methyl ester & 2026 & fatty acid methyl ester \\
3 & 20.08 & n-hexadecanoic acid & 1962 & saturated fatty acid \\
4 & 20.66 & 9,12 - octadecanoic acid (z, z)- & 2068 & polyunsaturated fatty acid \\
5 & 21.21 & octadecanoic acid & 2082 & saturated fatty acid \\
6 & 21.33 & tetracosanoic acid, methyl ester & 2433 & fatty acid methyl ester \\
\hline
\end{tabular}

${ }^{\mathrm{a}}$ Retention Index (HP-5ms column), ${ }^{\mathrm{b}}$ Compounds listed in order of elution from a HP-5MS column

\section{Conclusion}

The bioactivity of $B$. vulgaris, which has been found to exhibit anti-microbial, anti-inflammatory, and anti-cancer effects, can be linked to the chemical constituents found inherently in the fruit. The edible berry was established to contain significant amounts of chlorogenic acid $(47.1 \mathrm{mg} / \mathrm{kg})$, rutin $(0.02 \mathrm{mg} / \mathrm{kg})$ and berberine $(0.36 \mathrm{mg} / \mathrm{kg}) \mathrm{which}$ have been observed to have medical applications and could be responsible for the observed high antioxidant potential in the DPPH assay $\left(\mathrm{IC}_{50}=34.48 \mu \mathrm{g} / \mathrm{mL}\right.$ crude extract). The bacteriostatic potential of these constituents could be linked to the ability of these entities to penetrate cell membranes, thereby affecting the integrity of the microbes, and to inhibit quorum-sensing. A substantial amount of zinc, iron, and medium to long chain free fatty acids were also detected in the samples which have been reported to induce the degradation of pathogens and malignant neoplasms. The pharmacognosy involved could be correlated to the translational capacity of these constituents to induce caspase-dependent apoptosis, quenching of reactive oxygen species, regulation of phase I or phase II enzymes, and the expression of anti-inflammatory agents.

\section{Acknowledgement}

A research grant from De La Salle University Science Foundation through the University Research Coordination Office is gratefully acknowledged.

\section{References}

1. Shamsa, F., Ahmadiani, A. and Khosrokhavar, R. (1999). Antihistaminic and anticholinergic activity of barberry fruit (Berberis vulgaris) in the guinea-pig ileum. Journal of Ethnopharmacology, 64(2):161-166.

2. Taheri, S., Zarei A., Ashtiyani, S. C., Rezaei, A. and Zaheiri, S. (2012). Evaluation of the effects of hydroalcoholic extract of Berberis vulgaris root on the activity of liver enzymes in male hypercholesterolemic rats. Avicenna Journal of Phytomedicine, 2(3): 153-161.

3. Koncic, M. Z., Kremer, D., Karlovic, K. and Kosalec, I. (2010). Evaluation of antioxidant activities and phenolic content of Berberis vulgaris L. and Berberis croatica Horvat. Food and Chemical Toxicology, 48: 2176-2180.

4. Sikder, A. A., Kuddus, R., Kasier, A. and Arshad, W. M. (2010). In vitro membrane stabilizing activity, total phenolic content, free radical scavenging and cytotoxic properties of Aphanamixis polystachya (Wall.). Bangladesh Pharmaceutical Journal, 13(2): 55-59.

5. Hasler, A., Sticher, O. and Meier, J. (1992). Identification and determination of the flavonoids from Ginkgo biloba by high-performance liquid chromatography. Journal of Chromatography, 605(1): 41-48.

6. Olszewska, M. (2007). Quantitative HPLC analysis of flavonoids and chlorogenic acid in the leaves and Inflorescences of Prunus serotina Ehrh. Acta Chromatographica, 19: 253-269.

7. Gordon, M. H. and Wishart, K. (2010). Effects of chlorogenic acid and bovine serum albumin on the oxidative stability of low density lipoproteins in vitro. Journal of Agriculture Food Chemistry, 58: 5828-5833. 
8. Boettler, U., Volz Pahlke, N. G., Teller, N., Kotyczka, C., Somoza, V., Stiebitz, H., Bytof, G., Lantz, I., Lang, R., Hofmann, T. and Marko, D. (2011). Coffees rich in chlorogenic acid or N-methylpyridinium induce chemopreventive phase II-enzymes via the Nrf2/ARE pathway in vitro and in vivo. Molecular Nutrition and Food Research, 55: 798-802.

9. Wang, G. F., Shi, L. P., Ren, Y. D., Liu, Q. F., Liu, H. F., Zhang, R. J., Li, Z., Zhu, F. H., He, P. L., Tang, W., Tao, P. Z., Li, C., Zhao, W. M. and Zuo, J. P. (2009). Anti-hepatitis B virus activity of chlorogenic acid, quinic acid and caffeic acid in vivo and in vitro. Antiviral Research, 83: 186-190.

10. Sato, Y., Itagaki, S., Kurokawa, T., Ogura, J., Kobayashi, M., Hirano, T., Sugawara, M. and Iseki, K. (2011). In vitro and in vivo antioxidant properties of chlorogenic acid and caffeic acid. International Journal of Pharmaceutics, 403: 136-138.

11. Gordon, T., Perlstein, B., Houbara, O., Felner, I., Banin, E. and Margel, S. (2011). Synthesis and characterization of zinc/iron oxide composite nanoparticles and their antibacterial properties. Colloids and Surfaces A: Physicochemical Engineering Aspects, 374(1-3): 1-8.

12. Tang, Y. Z. and Liu, Z. Q. (2008). Chemical kinetic behavior of chlorogenic acid in protecting erythrocyte and DNA against radical-induced oxidation. Journal of Agriculture and Food Chemistry, 56: 11025-11029.

13. Khan, M. M., Ahmad, A., Ishrat, T., Khuwaja, G., Srivastawa, P., Khan, M. B., Raza, S. S., Javed, H., Vaibhav, K., Khan, A. and Islam, F. (2009). Rutin protects the neural damage induced by transient focal ischemia in rats. Brain Research, 1292: 123-135.

14. Lin, J. P., Yang, J. S., Lin, J. J., Lai, K. C., Lu, H. F., Ma, C. Y., Sai-Chuen W. R. Wu, K. C., Chueh, F. S., Gibson, W. and Chung, J. G. (2012). Rutin inhibits human leukemia tumor growth in a murine xenograft model in vivo. Environmental Toxicology, 27(8): 480-484.

15. Iawasa, K., Kamigauchi, M., Suguira, M., Nanba, H. (1997). Antimicrobial activity of some 13-alkyl a substituted protoberberinium salts. Planta Medica, 63(3): 196-198.

16. Muller, K., Ziereis, K. and Gawlik, I. (1995). The antisporatic Mahonia aquifolium and its active constituents; II. Antiproliferative against cell growth of human keratinocytes. Planta Medica, 61(1): 74-75.

17. Kettman, V., Kosfalova, D., Jantova, S., Cernakova, M. and Drimal, J. (2004). In vitro cytotoxicity of berberine against HeLa and L1210 cancer cell lines. Pharmazie, 59(7): 548-551.

18. Ling, C. A., Mahmud, S., Khadijah, S., Bakhori, M., Sirelkhatim, A., Mohamad, D., Hasan, H., Seeni, A. and Rahman, R. A. (2013). Antibacterial responses of zinc oxide structures against Staphylococcus aureus, Pseudomonas aeruginosa and Streptococcus pyogenes. Ceramics International, 40(2): 2993-3001.

19. Gordon, T., Perlstein, B., Houbara, O., Felner, I., Banin, E. and Margel, S. (2011). Synthesis and characterization of zinc/iron oxide composite nanoparticles and their antibacterial properties. Colloids and Surfaces A: Physicochemical and Engineering Aspects, 374(1-3): 1-8.

20. Isaacs, C. E., Kim, K. S. and Thormar, H. (1994). Inactivation of enveloped viruses in human bodily fluids by purified lipids. Annals of the New York Academy of Sciences, 724: 457-464.

21. Petschow, B. W., Batema, R. P. and Ford L. L. (1996). Susceptibility of Helicobacter pylori to bactericidal properties of medium-chain monoglycerides and free fatty acids. Antimicrobial Agents and Chemotherapy, 40: 302-306.

22. Isaacs, C. E., Litov, R. E. and Thormar, H. (1995). Antimicrobial activity of lipids added to human milk, infant formula, and bovine milk. The Journal of Nutritional Biochemistry, 6: 362-366.

23. Bergsson, G., Steingrímsson, O. and Thormar, H. (2002). Bactericidal effects of fatty acids and monoglycerides on Helicobacter pylori. International Journal of Antimicrobial Agents, 20(4): 258-262.

24. Wang, Y., Lu, J., Ruth, M. R., Goruk, S. D., Reaney, M. J., Glimm, D. R., Vine, D. F. and Field, C. J. (2008). Trans-11 vaccenic acid dietary supplementation induces hypolipidemic effects in JCR:LA-cp rats. Journal of Nutrition, 138(11): 2117-2122.

25. Lim,, J. N., Oh, J. J., Wang, T., Lee, J. S., Kim, S. H., Kim, Y. J. and Lee, H. G. (2014). Trans-11 18:1 vaccenic acid (TVA) has a direct anti-carcinogenic effect on MCF-7 human mammary adenocarcinoma cells. Nutrients, 6(2): 627-636. 